\title{
Keep Calm and Comp. Cog. On. Commentary: A crisis in comparative psychology: where have all the undergraduates gone?
}

\author{
Valerie A. Kuhlmeier* and Mary C. Olmstead \\ Department of Psychology, Queen's University, Kingston, ON, Canada
}

Keywords: comparative psychology, comparative cognition, undergraduates, graduate programs, education, cognition, evolution

\section{A commentary on}

A crisis in comparative psychology: where have all the undergraduates gone? by Abramson, C. I. (2015). Front. Psychol. 6:1500. doi: 10.3389/fpsyg.2015.01500

\section{OPEN ACCESS}

Edited by:

Christopher B. Sturdy, University of Alberta, Canada

Reviewed by:

Eduardo Mercado, University at Buffalo, The State University of New York, USA Jerome Cohen,

University of Windsor, Canada

${ }^{*}$ Correspondence:

Valerie A. Kuhlmeier vk4@queensu.ca

Specialty section: This article was submitted to Comparative Psychology, a section of the journal

Frontiers in Psychology

Received: 15 December 2015 Accepted: 07 January 2016 Published: 25 January 2016

Citation:

Kuhlmeier VA and Olmstead MC (2016) Keep Calm and Comp. Cog.

On. Commentary: A crisis in comparative psychology: where have all the undergraduates gone?

Front. Psychol. 7:20.

doi: 10.3389/fpsyg.2016.00020
Full Disclosure: We have recently authored an undergraduate textbook entitled Comparative Cognition (Olmstead and Kuhlmeier, 2015). Our motivation to write this book did not result from a perceived lack of undergraduate interest in the topic, but rather overenrolled courses for which we did not have a textbook.

A key difference between our approach-largely shared by fellow commenters Brodbeck and Brodbeck (2015) and McMillan and Sturdy (2015)_-and that of Abramson (2015), is our willingness to work under the title "comparative cognition." We have been trained under various titles (e.g., biological anthropology, behavioral ecology, ethology, cognitive psychology, developmental psychology, and behavioral neuroscience) and have witnessed the continued emergence of comparative cognition as the logical intersection of these disciplines. Though, still considered a narrowly focused field by Abramson, we propose instead that comparative cognition has broadened (or perhaps always was broad, see Hulse et al., 1978; Wasserman, 1981), and encompasses, without conflict, Abramson's defining features of comparative psychology.

Our point here goes beyond an argument about semantics, though it is important to be clear about our use of "comparative cognition," Take, for example, a statement in the commentary by Bielert and Gallup (2015): "In particular, comparative cognition is quite similar to comparative psychology aside from restricting its research questions and measures to those specific to information processing (Shettleworth, 2010)." We do not see this "restriction" in scope in the modern practice of comparative cognition research. Instead, researchers consider the ways that general learning mechanisms may be constrained by early developing (perhaps innate) behavioral or perceptual biases, conceptual abilities, and/or non-conceptual processes.

So yes, comparative cognition is open to the possibility of cognitive processes, but it actively tests for them. It also goes far beyond comparing behavioral responses of "species X" to that of humans (an anthropocentric approach that only a subset of researchers adopt, often with appropriate consideration of phylogenetics), and gone are the days of studying only a few, unrelated species. To use one metric: at the 2015 meeting of the Comparative Cognition Society, research with over 20 different species was presented. Shettleworth (2009), a pioneer and leader in the field, noted that comparative cognition research in the first decade of the twenty-first century was characterized by an increasing number of species examined and more synergy with related fields, such as behavioral ecology. 
A scholar of comparative cognition-and we think Shettleworth would agree with this based on her 2010 book-should be knowledgeable about sensory systems, behavioral tenets including general associative learning mechanisms, memory, and proposed cognitive mechanisms that are implicated in such areas as categorization, spatial navigation, number, timing, prosocial behavior, communication, and social learning, all the while considering an evolutionary, developmental, and neuroscientific framework. It's a tall order, but what an exciting field!

In our experience, undergraduates agree. Like fellow commenters Furlong et al. (2015), we see the "missing" undergraduates every week-200 of them this term alone in a second year survey course: Introduction to Comparative Cognition. Many of these students will take our upper level laboratory courses that focus on specialized topics within the field of comparative cognition. The majority of these students specialize in other areas of psychology such as developmental, clinical, or cognitive psychology, a number

\section{REFERENCES}

Abramson, C. I. (2015). A crisis in comparative psychology: where have all the undergraduates gone? Front. Psychol. 6:1500. doi: 10.3389/fpsyg.2015. 01500

Bielert, C. F., and Gallup, A. C. (2015). A clarion call or a swan song? Commentary: a crisis in comparative psychology: where have all the undergraduates gone? Front. Psychol. 6:1867. doi: 10.3389/fpsyg.2015.01867

Brodbeck, M. I. R., and Brodbeck, D. R. (2015). It's just evolution. Commentary: a crisis in comparative psychology: where have all the undergraduates gone? Front. Psychol. 6:1873. doi: 10.3389/fpsyg.2015.01873

Furlong, E. E., AuBuchon, S., Kraut, J., Joiner, N., Knowles, J., Lewis, K., et al. (2015). From crisis to crowd control. Commentary: a crisis in comparative psychology: where have all the undergraduates gone? Front. Psychol. 6:1729. doi: 10.3389/fpsyg.2015.01729

Hulse, S. H., Fowler, H., and Honig, W. K. (1978). Cognitive Processes in Animal Behavior. Hillsdale, NJ: Lawrence Erlbaum Associates.

McMillan, N., and Sturdy, C. B. (2015). Commentary: a crisis in comparative psychology: where have all the undergraduates gone? Front. Psychol. 6:1589. doi: 10.3389/fpsyg.2015.01589 are biology or life science majors, and a handful come from complementary disciplines such as computer science or philosophy. And yes, occasionally students seek out graduate study in laboratories specifically focused on comparative cognition. Regardless, we trust that they all pursue their chosen area of study with a greater appreciation and engagement in the basic, comparative science that informs so many fields of study.

\section{AUTHOR CONTRIBUTIONS}

All authors listed, have made substantial, direct and intellectual contribution to the work, and approved it for publication.

\section{FUNDING}

This work was funded by a Discovery Grant to VK from the Natural Sciences and Engineering Council of Canada.

Olmstead, M. C., and Kuhlmeier, V. A. (2015). Comparative Cognition. Cambridge: Cambridge University Press.

Shettleworth, S. J. (2009). The evolution of comparative cognition: is the snark still a boojum? Behav. Processes. 80, 210-217. doi: 10.1016/j.beproc.2008.09.001

Shettleworth, S. J. (2010). Cognition, Evolution and Behavior, 2nd Edn. Oxford: Oxford University Press.

Wasserman, E. A. (1981). Comparative psychology returns: a review of Hulse, Fowler, and Honig's Cognitive Processes in Animal Behavior. J. Exp. Anal. Behav. 35, 243-257.

Conflict of Interest Statement: The authors declare that the research was conducted in the absence of any commercial or financial relationships that could be construed as a potential conflict of interest.

Copyright (C) 2016 Kuhlmeier and Olmstead. This is an open-access article distributed under the terms of the Creative Commons Attribution License (CC BY). The use, distribution or reproduction in other forums is permitted, provided the original author(s) or licensor are credited and that the original publication in this journal is cited, in accordance with accepted academic practice. No use, distribution or reproduction is permitted which does not comply with these terms. 